Synthesis, part of a Special Feature on Telecoupling: A New Frontier for Global Sustainability

\title{
Polycentric governance in telecoupled resource systems
}

\author{
Christoph Oberlack $^{1,2}, \underline{\text { Sébastien Boillat }}^{1}, \underline{\text { Stefan Brönnimann }}^{1,3}, \underline{\text { Jean-David Gerber }}^{1,4}$, Andreas Heinimann $^{1,2}$, Chinwe Ifejika $^{1,2}$ \\ Speranza $^{1}$, Peter Messerli ${ }^{1,2}$, Stephan Rist ${ }^{1,2}$ and Urs Wiesmann ${ }^{1,2}$
}

\begin{abstract}
Recent advances in land system science and in institutional analysis provide complementary, but still largely disconnected perspectives on land use change, governance, and sustainability in social-ecological systems, which are interconnected across distance. In this paper we bring together the emerging concept of telecoupled land systems and the established concept of polycentric governance to support the analysis and the development of sustainable land governance in interconnected social-ecological systems. We operationalize the two concepts by analyzing networks of action situations in which interactions between proximate and distant actors as well as socioeconomic and ecological processes cause land use change and affect the sustainability of land systems. To illustrate this integrated approach empirically, we analyze a case of transnational biofuel investment in Sierra Leone. We identify the characteristics of, and activities in, networks of action situations that affect the sustainability of land systems related to this case. Integration of the two concepts of telecoupled land systems and polycentric governance enables analysts to identify interactions in polycentric governance systems (1) as drivers of telecoupled sustainability problems and (2) as transformative approaches to such problems. The method provides one way for linking place-based analysis of land change with process-based analysis of land governance.
\end{abstract}

Key Words: institutional analysis; land system science; natural resources; networks of action situations; polycentric governance; telecoupling

\section{INTRODUCTION}

Land use change and land governance are increasingly shaped by factors and processes that originate in places both proximate and distant to the places of their effects (Meyfroidt et al. 2013). Land use and land-use change in one region frequently displaces land use in other regions (Lambin and Meyfroidt 2011). Many smallscale social-ecological systems that were formerly characterized by internal feedbacks between their social and ecological subsystems have become connected with distant places (Brondizio et al. 2009). Such long-distance interactions constitute a major challenge in the governance of land and the sustainability of social-ecological systems (Verburg et al. 2015). Changes in land use and governance often entail new trade-offs between ecosystem services and between sustainability goals. They also lead to conflicts of interest between resource users with competing claims on natural resources. This omnipresence of trade-offs and competing claims underlines that transformations toward more sustainable land systems are fundamentally a question of justice, both distributional and procedural, to determine which sustainability values and resource claims prevail over others (Schlosberg 2013, Agyeman et al. 2016).

Land system science and institutional analysis provide complementary perspectives on land use change, governance, and sustainability in interconnected social-ecological systems. Land system scientists increasingly conceptualize long-distance interactions as "telecoupling," which refers to "socioeconomic and environmental interactions among coupled human and natural systems over distances" (Liu et al. 2013). The approach analyzes distant actors, flows, causes, feedbacks, and outcomes in distantly connected land systems (Eakin et al. 2014). Proponents of institutional analysis developed the concept and theory of "polycentric governance" to understand the emergence, change, and performance of complex governance systems (Ostrom 2010). Governance systems are polycentric if they involve multiple arenas of decision making, which operate with some degree of autonomy but are interlinked through processes of cooperation, coordination, or conflict (Pahl-Wostl and Knieper 2014, Carlisle and Gruby 2017). While telecoupling provides an analytical lens for distantly connected land systems, polycentricity provides a lens for interconnected governance arenas. Surprisingly, the two research perspectives have so far remained largely disconnected.

The integrative analysis of telecoupling and polycentricity allows researchers to address research questions on sustainability, which require a thorough understanding of both complex land systems and governance systems at the same time. For example, how do current dynamics in transnational resource regimes affect local and regional social-ecological systems? How do governance strategies in different arenas shape these dynamics? Which actors are able to shape social-ecological transformations toward sustainability?

We propose a way of linking the concepts of telecoupling and polycentric governance to support the analysis and the development of sustainable land governance in interconnected social-ecological systems. We operationalize the two concepts by analyzing networks of action situations (McGinnis 2011a, Kimmich 2013) in which interactions between proximate and distant actors as well as socioeconomic and ecological processes cause land change and affect the sustainability of land systems. We illustrate this approach with a case of transnational biofuel investment in Sierra Leone. The approach enables analysts to identify characteristics of, and activities in, polycentric governance systems as drivers of telecoupled sustainability problems and as transformative opportunities to tackling sustainability challenges. The method provides one way for linking place-based analysis of land change with process-based analysis of land governance.

\footnotetext{
${ }^{1}$ Institute of Geography, University of Bern, Switzerland, ${ }^{2}$ Centre for Development and Environment (CDE), University of Bern, Switzerland, ${ }^{3}$ Oeschger Centre for Climate Change Research, University of Bern, Switzerland, ${ }^{4}$ Centre for Regional Economic Development (CRED), University of Bern, Switzerland
} 


\section{THE SIGNIFICANCE OF TELECOUPLING FOR INSTITUTIONAL ANALYSIS}

Telecoupling conveys the idea of interactions and connectivity among multiple social-ecological systems over distance (Liu et al. 2013). The concept adapts the notions of physical teleconnections - a termed coined by Ångström (1935), which is defined as the interrelation of climatic anomalies over long distances - and societal teleconnections, such as flows of capital, people, or goods, for use in the study of land systems (Moser and Hart 2015). However, telecoupling departs from the concept of teleconnection. Physical teleconnection does not postulate cause-and-effect-relationships and focuses on relations between variables inside a physical system, whereas telecoupling focuses on causal relationships, multidirectional flows and feedbacks of land-use change in multiple, distantly connected socialecological systems (Friis et al. 2016). Although the concept of telecoupling has been proposed by land system scientists, its significance is not limited to land system science alone.

The telecoupling of land systems presents several major challenges and opportunities for institutional analysis. First, institutional analysis has been particularly successful in understanding the governance of small-scale resource systems (e.g., Ostrom 1990, Agrawal 2001, Cox et al. 2010) and regional to global resources (e.g., Young et al. 2008, Biermann 2014, Cox 2014a, Galaz 2014). However, telecoupled resource systems have specific features, which make them distinct to small- and largescale resource systems. Telecoupling entails a specific kind of interdependence between local and distant actors who are embedded in multiple distinct but connected social-ecological systems (Paavola 2007). One example is transnational, agroindustrial investments in land. Transnational capital often modifies common property regimes in its target regions (Dell'Angelo et al. 2017a). Meanwhile, it also affects other regions, for example by causing migration and transnational trade, while reducing pressure on land in the investor's region of origin. A telecoupled system may require governance solutions that are neither local nor global: local institutions with clear boundaries may be overwhelmed by interactions with systems to which they are distantly connected. By contrast, global institutions, such as agreements between UN member states, may be too unspecific to address telecoupling, which is often characterized by key interactions in a small number of countries (Challies et al. 2014, Lenschow et al. 2016). Even though institutional analysis has long taken note of the globalization of social-ecological systems (Young et al. 2006) and their connectivity (Brondizio et al. 2009), institutional theories remain far less developed to explain sustainability in telecoupled resource systems compared to small- or large-scale resource systems.

Second, recent research has conceived of such connectivity as "disturbance" to local social-ecological systems (e.g., Anderies and Janssen 2011, Cox 2014b), examining disturbances as exogenous drivers of institutional and social-ecological change. Analysis of telecoupling allows endogenizing the origins and polycentric governance of many of these disturbances in an integrated analysis, thus expanding the focus beyond adaptation to disturbances (Villamayor-Tomás 2014).
Third, the telecoupling lens emphasizes analysis of flows, which link social-ecological systems (Liu et al. 2013). Theories of polycentric governance (e.g., McGinnis 1999, Ostrom 2010) and governance in networks (e.g., Pattberg 2010, Reinecke et al. 2014) can expand their scope by analyzing the social, ecological, economic, and political flows that create interdependency between local and distant actors and link multiple governance arenas.

In sum, we argue that research on telecoupling provides a prime opportunity to expand the scope of institutional analysis by (1) systematically expanding the scope of institutional analysis from nested levels of spatial scale (small to large resources; local to global institutions) to networks and connectivity among social-ecological systems; (2) advancing theories of polycentric governance systems; and (3) revealing how distant actors and connecting flows influence the sustainability of resource governance and use.

\section{THE SIGNIFICANCE OF POLYCENTRICITY FOR LAND GOVERNANCE IN TELECOUPLED SYSTEMS}

Land system science seeks to understand the complex interactions between social and ecological processes at various levels of spatial scale and incorporates the analysis of decision making (Turner et al. 2007, Reenberg 2009, Rounsevell et al. 2012). A polycentric approach can support scientists and policymakers in using their "understanding [of land systems change] to design sustainable transformations through stakeholder engagement and through the concept of land governance" (Verburg et al. 2015:29). This is particularly true for land systems that are telecoupled, because the interconnected and multiscalar nature of telecoupled systems has important implications for land governance (Lenschow et al. 2016). Governance mechanisms embedded in a single decision-making arena, such as a central government or a local community, fail to provide effective solutions if they disregard the autonomy of actors who affect land change in connected arenas (Nagendra and Ostrom 2012). If the systems of concern are multilevel and interconnected, effective sustainability transformations require coordinated governance in multiple arenas, i.e., a high degree of polycentricity (Galaz et al. 2012).

The concept of polycentric governance provides a wellestablished analytical approach for understanding and designing such governance in complex systems (Ostrom 2010). A polycentric approach to telecoupled systems may achieve at least three important contributions to land system science.

First, while land governance is partly shifting from territorial, e.g., state-based, to flow-centered arrangements, e.g., product certification schemes, multiple territorial and flow-centered governance arrangements often coexist (Sikor et al. 2013). Tensions among them create fragmented institutional systems, and their interaction generates land system outcomes. Polycentricity provides a lens for analyzing diverse coexisting governance arrangements and their interactions based on a single consistent concept (Aligica and Tarko 2012, Thiel 2016).

Second, analysis and design of land governance in telecoupled systems can draw on established institutional theories and evidence concerning the structure and functioning of polycentric systems. For example, if a wide array of 
Fig. 1. Framework linking the concepts of telecoupled social-ecological systems and polycentric governance based on networks of action situations. Source: Authors, based on GLP 2005, Ostrom 2005, 2009, Liu et al. 2013, Eakin et al. 2014, McGinnis and Ostrom 2014, Moser and Hart 2015.

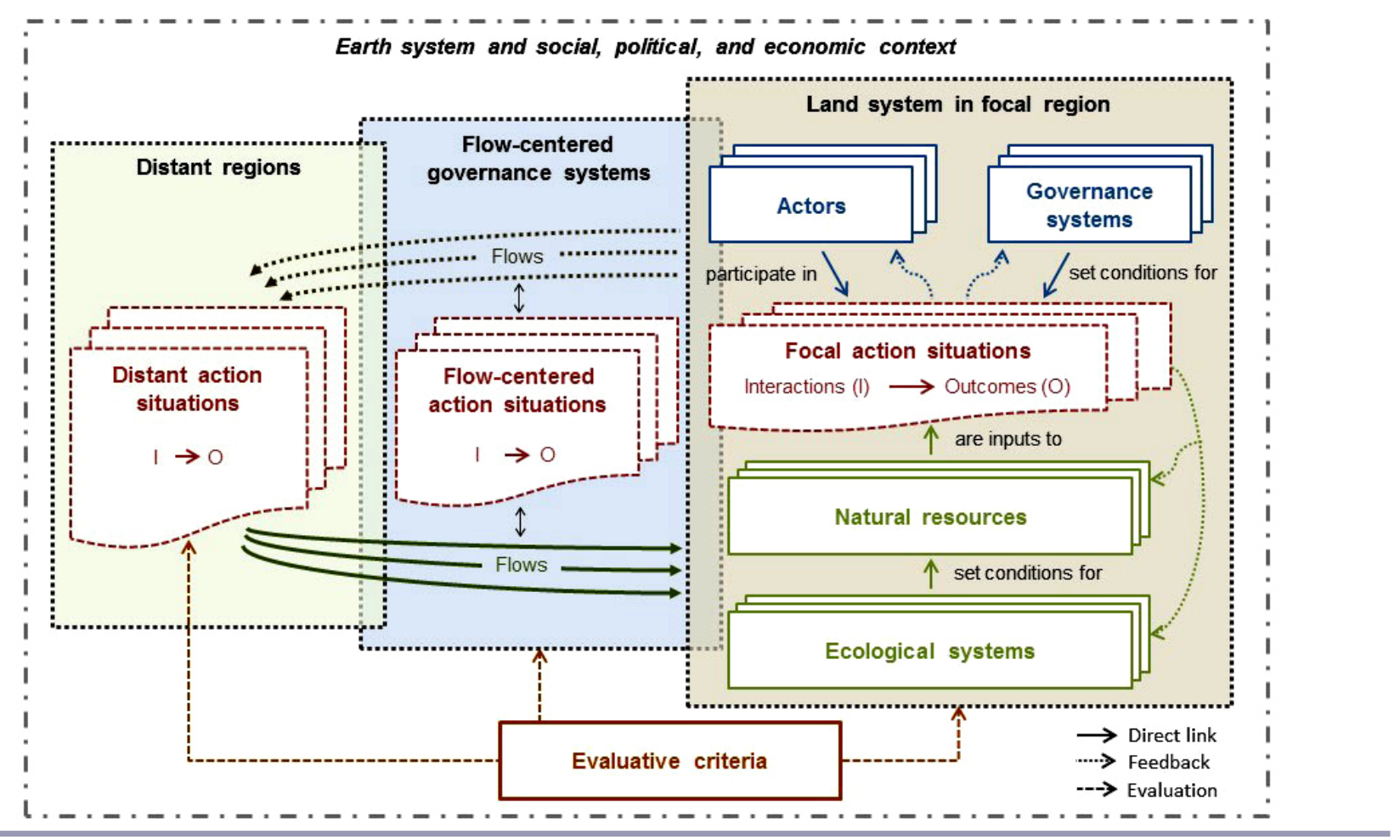

interdependent actors face complex decision problems that affect multiple places, involve connected risks, and cut across multiple governance levels, if potential governance responses provide benefits at multiple scales and levels, and if the responses are most effectively organized at multiple decision-making levels, polycentric systems increase the likelihood that governance solutions fit the governance problems in specific contexts (Dietz et al. 2003, Berkes 2007, Biggs et al. 2012, Pahl-Wostl et al. 2012, Galaz 2014). Telecoupled land systems fulfill all of the above conditions. Further, polycentric systems provide opportunities to organize collective action at those institutional levels that best fit the levels, at which ecosystems generate services (Folke et al. 2005). At the same time, polycentricity is neither a sufficient nor a necessary condition for tackling all kinds of land governance problems. Polycentric systems may encounter problems of leakage, incoherent policies, slowness, and free riding (Duit and Galaz 2008, Osberghaus et al. 2010). They can encourage individuals to further particularistic interests at the expense of others by (re)scaling governance (Thiel and Eggerton 2011), and can institutionalize tensions between actors with conflicting agendas (Galaz et al. 2012). Therefore, analysts need to engage in precise diagnosis and analysis of polycentric governance systems, telecoupled land systems, and their impacts on specific sustainability indicators.

Third, analysis of polycentric systems is increasingly operationalized as analysis of networks of action situations (NAS; e.g., Villamayor-Tomás et al. 2015, Grundmann and Ehlers 2016, Knüppe and Knieper 2016). We show in this paper how the NAS concept can serve to operationalize the concepts of telecoupling and polycentric governance for integrated analysis, and how this approach can locate the causes of sustainability problems and the scope for transformative change in specific arenas of social-ecological interaction. Taken together, the polycentric approach and its operationalization using NAS is one possible response to the current need "for novel research methods to describe and assess land governance systems" identified in land system science (GLP 2016:18).

\section{LINKING AND OPERATIONALIZING ANALYSIS OF TELECOUPLED SYSTEMS AND POLYCENTRIC GOVERNANCE}

Linking telecoupled systems and polycentric governance

We propose a way of linking analysis of telecoupling and of polycentricity by analyzing networks of action situations (NAS). NAS convey the idea that we can analyze complex governance systems and the social-ecological systems they are part of by disentangling linked spaces of social-ecological interaction that generate outcomes, e.g., land use and land cover changes related to deforestation, urbanization, or agricultural intensification (Fig. 1).

An action situation consists of "participants in positions who [take] diverse actions in light of the information [and control] they possess about how actions are linked to potential outcomes and the costs and benefits assigned to actions and outcomes" (McGinnis 2011b:173-174, Ostrom 2005). Action situations "are the social spaces where individuals interact, exchange goods and services, solve problems, dominate one another, or fight (among 
the many things that individuals do in action situations)" (Ostrom 2011:11). Actors have different dispositions, depending for example on their education, social networks, and wealth, to be assigned to or to take certain positions and actions.

In the terminology of land system science proposed by Verburg et al. (2015:29), researchers can use the concept of action situations to analyze the social spaces of land governance in which "activities related to the human use of land" occur; which are shaped by, and shape, land change processes; and where the intended and "unintended social and ecological outcomes of societal activities" are generated. Governance is the process by which actors form, apply, interpret, and reform the repertoire of rules, norms, and strategies that guide decision making (Hufty 2011, McGinnis 2011b).

The structure of an action situation is shaped by a set of variables. They can be thought of as the properties of social-ecological systems (SES), as illustrated in the right-hand part of Figure 1 based on GLP (2005) and Ostrom (2009). Ecological systems consist of the multiple interacting and dynamic ecological processes that condition the generation of natural resources (Vatn 2005). Resources are defined in relation to specific uses by actors, involving their valuation of the environment and their demand for ecosystem services (Gerber et al. 2009). Actors are individuals or collective entities who pursue activities by using a set of means for specific intentions (Wiesmann et al. 2011). Governance systems comprise the set of rules, rights, procedures, and network structures that guide activities of actors. An SES is embedded in a broader earth system, social, political, and economic context. Together, the attributes of ecological systems, resources, actors, governance systems and context condition social and social-ecological interactions. These interactions take place in one or more action situations and generate outcomes. They generate feedbacks by changing the properties of an SES (McGinnis and Ostrom 2014) and by sending flows (Liu et al. 2013). Land systems "constitute the terrestrial component of the Earth system and encompass all processes and activities related to the human use of land (...) as well as the benefits gained from land and the unintended social and ecological outcomes of societal activities" (Verburg et al. 2015:29). Evaluative criteria such as sustainability, justice, efficiency, legitimacy, and others can be used by participants or external observers of an action situation to assess interactions and outcomes (Ostrom 2005). This framework investigates temporal dynamics by analyzing feedbacks (dotted lines in Fig. 1) and by using dynamic variables that characterize change in the system components.

To analyze telecoupled systems, we need to zoom out of the SES in the focal region of research to understand interactions with systems in connected, distant regions. This comes with the practical challenge that a full-fledged SES analysis for all sending, receiving, and spillover systems (Liu et al. 2013) will often exceed the financial and time capacities of a single research project. Therefore, we propose to analyze interactions in distant action situations that exert relevant influence on land use in the focal SES, or that are influenced by the focal SES, rather than analyzing entire distant SESs. Researchers can identify distant action situations empirically by following the flows that shape land use. Distant action situations are characterized by actors, interactions, and outcomes, as described above, and they are shaped by ecological, socioeconomic, and institutional factors.
Research can produce more or less detailed insights into those distant action situations, depending on their research questions and capacities.

Earlier applications of the telecoupling framework described flows to highlight the deep interconnectedness of land systems (e.g., Liu 2014). The NAS approach makes it possible to expand this focus on flows by also analyzing their governance in flow-centered governance systems, i.e., "governance that targets particular flows of resources or goods" such as product certification schemes (Sikor et al. 2013:522). Figure 2 illustrates how the NAS approach can be used to zoom into flow-centered governance arrangements for their explicit analysis.

Action situations are linked if outcomes or actors of one situation affect the properties of another situation (Kimmich 2013). In telecoupled systems, action situations in a given SES and distant action situations are linked through flows. Moser and Hart (2015) distinguish six types of flows: goods and materials, money, energy, information and ideas, biological agents, and people (Fig. 2). Kimmich (2013) distinguishes four types of linkages between action situations biophysical transactions, information, institutions, and actors involved.

The configuration of action situations in a focal land system, distant regions, and flow-centered governance systems, as well as the linkages among them constitute a network of action situations, or NAS. Polycentric governance occurs precisely in this NAS. Telecoupling of a focal region with distant regions occurs through the flows linking action situations in this focal and in distant regions.

In sum, the NAS approach links the analysis of telecoupled resource systems and polycentric governance by disentangling the network of action situations in the focal region of a study, in connected distant regions, and in flow-centered governance arrangements that are connected through flows. The action situations are the social spaces in which governance takes place and that result in land change in specific regions.

\section{A diagnostic procedure to operationalize telecoupled systems and polycentric governance}

In Table 1 we propose a procedure to operationalize the presented approach. It modifies the diagnostic procedure that Hinkel et al. (2015) developed for Ostrom's SES framework to capture the particularities of telecoupling and polycentricity. All steps may be performed by disciplinary or interdisciplinary research teams or in transdisciplinary coproduction of knowledge, depending on research goals and capacities.

The results of step 1, the formulated issues of land use, sustainability, or governance, the outcomes of interest and the precise research question, provide a major reference point for delineating the focal region and SES as well as the relevant flows and connected distant regions. Steps 2-4 characterize the actors, ecological processes, and institutions affecting the issue in question in the focal region. Step 5 characterizes the flows and flow-centered governance arrangements, and step 6 diagnoses the sources and effects of the flows in distant regions.

Each of these main components can be characterized by a set of variables. For example, actors can be characterized according to their means and assets at their disposal and their values, beliefs, and social capital, while ecosystems may be characterized according to their boundaries, productivity, equilibrium properties, fluxes and 
Fig. 2. Zooming into flow-centered governance systems. Source: Authors, based on Sikor et al. (2013) and Moser and Hart (2015).

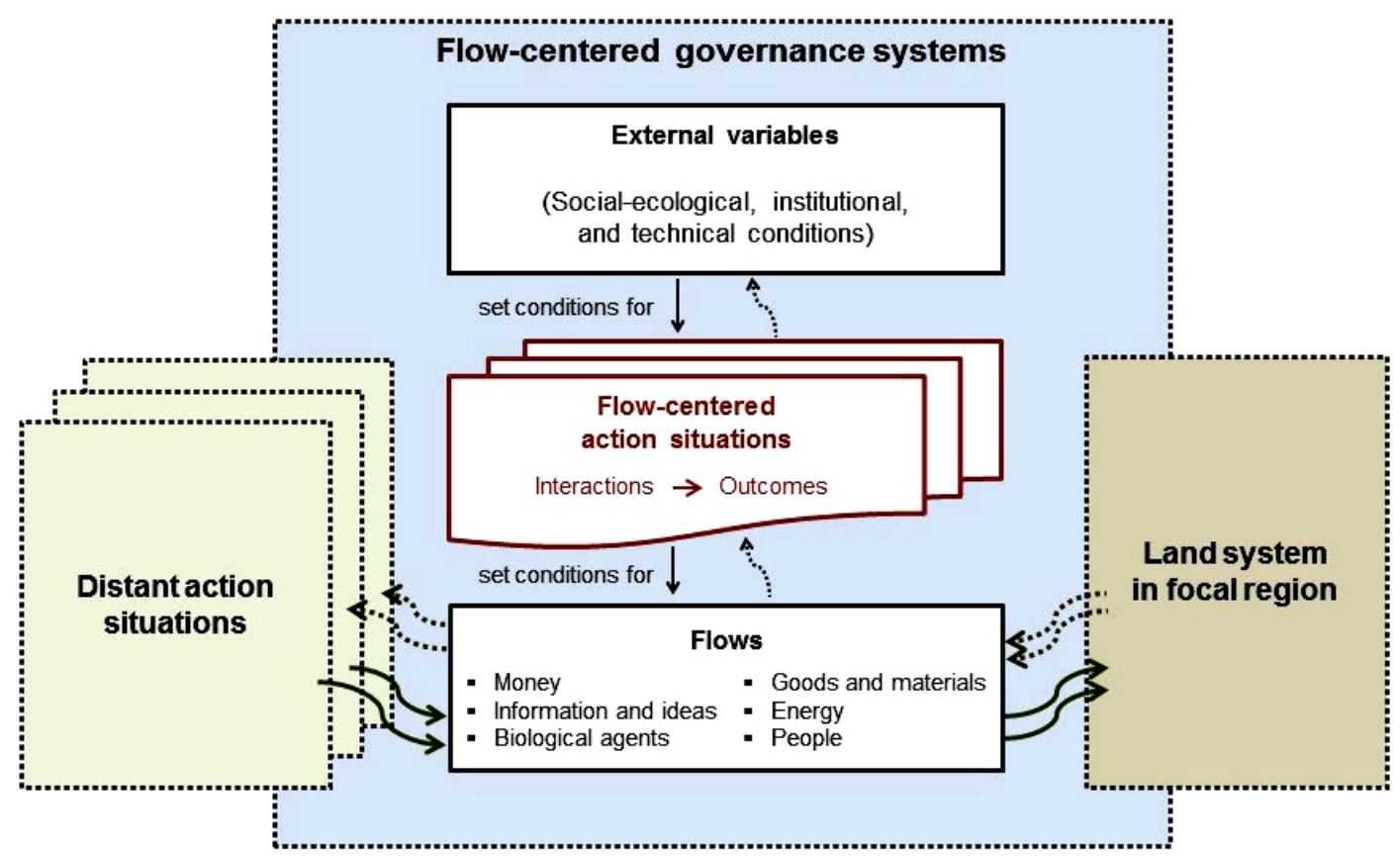

Table 1. Diagnostic procedure to operationalize telecoupled systems and polycentric governance for integrated analysis using networks of action situations.

\begin{tabular}{l}
\hline \hline Step Question \\
\hline 1 What are the land use, sustainability, or governance issues in \\
question? What is the research question? \\
Land system in focal region \\
2 What actors generate which benefits from which use of which \\
resources in the focal SES? Which actors are involved in \\
operational and collective choice activities affecting the resources? \\
What is the actors' agency, based on their assets, means, and \\
activities? \\
What ecological processes, e.g., climatic, hydrological, or \\
biological, affect natural resources and ecosystem services with \\
respect to the sustainability challenge identified in step 1? \\
4 What institutional arrangements, e.g., rules, rights, procedures, or \\
networks, regulate interactions in the focal SES? \\
Flows and flow-centered governance systems \\
5 What flows link the focal region with distant regions? How do \\
flow-centered governance systems shape, e.g., regulate, specific \\
flows? \\
Distant regions \\
6 How do ecological, socioeconomic, and institutional factors (static \\
or dynamic) shape interactions and outcomes in distant action \\
situations, including the connecting flows? What effects do flows \\
between the focal and distant regions have in the distant regions? \\
Network of action situations (focal, distant, and flow-centered) \\
7 What focal, distant, and flow-centered action situations affect the \\
land use, sustainability, or governance issue in question? What are \\
the linkages between the action situations? How do the ecological, \\
socioeconomic, and institutional factors identified in steps 2-6 \\
shape the interactions, linkages, and outcomes? \\
\hline
\end{tabular}

budgets of mass (e.g., carbon, nutrients, water), energy, and momentum (Wiesmann et al. 2011, McGinnis and Ostrom 2014). This array of variables can be organized in a multitiered diagnostic framework (Ostrom 2009), even though the establishment of a comprehensive multitiered map of variables for telecoupled systems is beyond the scope of this paper.

Steps 2-6 may be performed iteratively, including in multiple telecoupled regions. They are consistent for both hypothesistesting and inductive research.

Step 7 analyzes the network of action situations. It analyzes how the system properties identified in steps 2-6 generate activities and social-ecological interactions in a set of linked action situations, and to what effects.

As part of step 7, analysts need to decide how to delineate the boundaries of action situations. We identified six ways to delineate boundaries in prior NAS research. First, McGinnis (2011a) draws the boundaries in an NAS along generic functions performed by governance systems. These functions include production, provision, consumption, financing, coordination, dispute resolution, and rule making. Second, Villamayor-Tomás et al. (2015) delineate action situations along resources, focusing on water, energy, and food. Third, Grundmann and Ehlers (2016) draw the boundaries along the stages of the value chain of bioenergy. Fourth, Pahl-Wostl et al. (2010) and Schlüter et al. (2010) model the stages of a policy cycle as an NAS. A fifth option are the nested levels of local to global governance in multilevel systems (Hooghe and Marks 2003). The sixth option, chosen in this paper's application in the next section, is to draw boundaries along the situations of social interaction. These are distinct patterns of cooperation, coordination, and conflict among 
Fig. 3. Stylized timeline of main activities and events in the Addax Bioenergy in Sierra Leone (ABSL) case. Sources: Manley et al. 2011, Bürgi 2015, Fielding et al. 2015, AOG 2016, Bottazzi et al. 2016, Marfurt et al. 2016, SiLNoRF and BfA 2016. Yellow boxes denote main actors. Abbreviations: ABSL: Addax Bioenergy Sierra Leone, AOG: Addax Oryx Group.

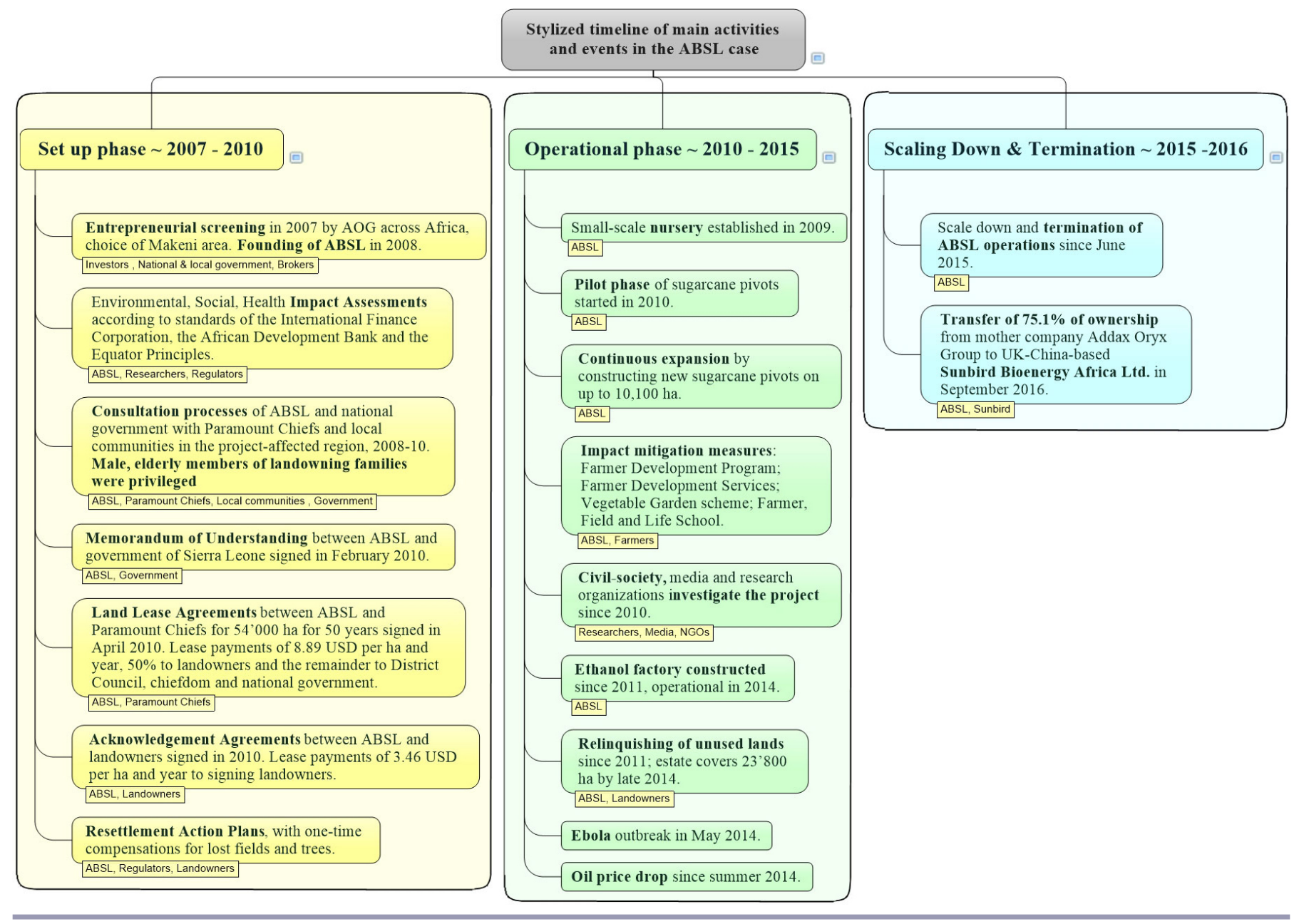

particular actors on particular governance issues generating particular outcomes (Lubell 2013). For example, Kimmich and Villamayor-Tomás (2018) show how interactions in a set of linked prisoner dilemma and coordination situations cause differential performance in irrigation systems in India and Spain. Boundaries within an NAS depend on the research purpose, in particular on the outcomes of interest, for which the NAS is developed as an explanation, and on the influence of action situations on the outcome of interest (Kimmich 2013).

Taken together, this diagnostic procedure links and operationalizes telecoupled systems and polycentric governance by analyzing linked action situations in multiple regions that are connected through flows. The framework and procedure are consistent with different quantitative and qualitative methods for data collection in empirical applications.

\section{POLYCENTRIC GOVERNANCE IN TELECOUPLED RESOURCE SYSTEMS: THE CASE OF A LARGE-SCALE BIOFUEL INVESTMENT IN SIERRA LEONE}

To illustrate this approach, we operationalize telecoupling and polycentricity by applying the NAS approach to the case of the biofuel investment by Addax Bioenergy in Sierra Leone (ABSL). The analysis draws on publications from various research projects on the case (Knoblauch et al. 2014, Bürgi 2015, Fielding et al. 2015, Yengoh and Armah 2015, Yengoh et al. 2015, 2016, Bottazzi et al. 2016, Marfurt et al. 2016, Mann 2016, Millar 2016a,b, Mann and Bürgi Bonanomi 2017, Bottazzi et al., in press), ABSL's environmental, social, and health impact assessment (Manley et al. 2011), and reports by civil society organizations (Anane and Abiwu 2011, SiLNoRF and BfA 2016). A coauthor of this paper has led one of the multiyear research projects.

\section{The ABSL case}

Figure 3 provides a stylized timeline of main activities and events of the ABSL case between 2007 and 2016. ABSL was founded in 2008 to implement an agroindustrial project to grow irrigated sugarcane and to produce $85,000 \mathrm{~m}^{3}$ ethanol per year in Sierra Leone for export to European fuel markets. The project was expected to provide $32 \mathrm{MW}$ of nominal electrical power capacity. The land lease initially comprised 54,000 ha but was later reduced to $23,800 \mathrm{ha}$. The land is located between 10 and $30 \mathrm{~km}$ southwest of the city of Makeni in northern Sierra Leone. African and 
European development finance institutes supported the project with EUR 267 million. In 2013 it was registered under the UN Kyoto Protocol's Clean Development Mechanism. ABSL complied with major international standards, including those of the Roundtable on Sustainable Biofuels, the International Finance Corporation's Performance Standards, the African Development Bank's environmental and social policies, and the Equator Principles. Nationally, the project complied with Sierra Leone's National Sustainable Agriculture Development Plan and its poverty reduction strategy, among others.

The project led to significant land use and land cover change. It converted 10,100 ha of seasonally flooded wetlands (bolilands), grass- and scrubland, and perennial swamps to irrigated sugarcane fields and an ethanol factory. An additional 2000 ha were used for a farmer development program, about 300 ha for infrastructure development, 23 ha for resettling households, and 1800 ha were left as ecological corridors and buffer zones. Previously, families in the 53 directly affected villages (estimated population: 13,600-25,000) had used the land mostly for subsistence agriculture, practicing small-scale settled farming, shifting cultivation, and charcoal production (Manley et al. 2011, SiLNoRF and BfA 2016).

\section{Sustainability challenges in linked action situations in the Addax case}

This section identifies interactions in a polycentric governance system as drivers of sustainability challenges in the telecoupled systems involved in the ABSL case. We focus on increased inequalities within project-affected communities as a major challenge in the ABSL case. We distinguish between inequalities in distribution, procedures, and recognition (Schlosberg 2013). The following research question guides our analysis: What interactions in linked action situations explain why the ABSL project reinforced inequalities within project-affected communities?

Table 2 describes the main features of the social-ecological system in the ABSL case (steps 1-4 of the diagnostic procedure) and distant action situations (step 6). Figure 4 depicts the new and modified flows through which the ABSL project intensified the telecoupling of land use in the Makeni area with distant regions in both Africa and Europe (step 5). Figure 5 shows the results of step 7.

Figure 5 displays the network of six action situations affecting community-level inequality. Three action situations are located in ABSL's focal region (brown color in Fig. 5): the land deal setup, project implementation, and community-based resistance. The European biofuel market and public policy is the main distant action situation, connected to the focal region through biofuel demand, supply, and regulations. Transnational regulatory spaces constitute the flow-centered action situations. Capital, duties, and legitimacy are the financial, regulatory, and ideational flows from transnational regulatory spaces to the focal region in Sierra Leone. Finally, activist, media, and research activities have occurred in the focal region, in Europe, and in transnational arenas. They affect the other action situations through flows of information promoting public deliberation and representation of actor voices. Figure 5 identifies specific actors, interaction issues, land system outcomes, and linkages for every action situation. This network of action situations constitutes the polycentric system that explains how the ABSL project has affected community-level inequality. It is a polycentric system because multiple semiautonomous arenas of decision making exist, which take each other into account in cooperative, coordinative, or conflictive manners (Carlisle and Gruby 2017). The project has increased inequalities within project-affected communities in two major ways. Arrows 1 and 2 in Figure 5 illustrate these direct effects.

Fig. 4. Flows intensifying the telecoupling of land use in the Addax Bioenergy in Sierra Leone (ABSL) target region with distant regions. Source: based on Manley et al. 2011, Bürgi 2015, Fielding et al. 2015, Bottazzi et al. 2016, Marfurt et al. 2016, Millar 2016a,b.

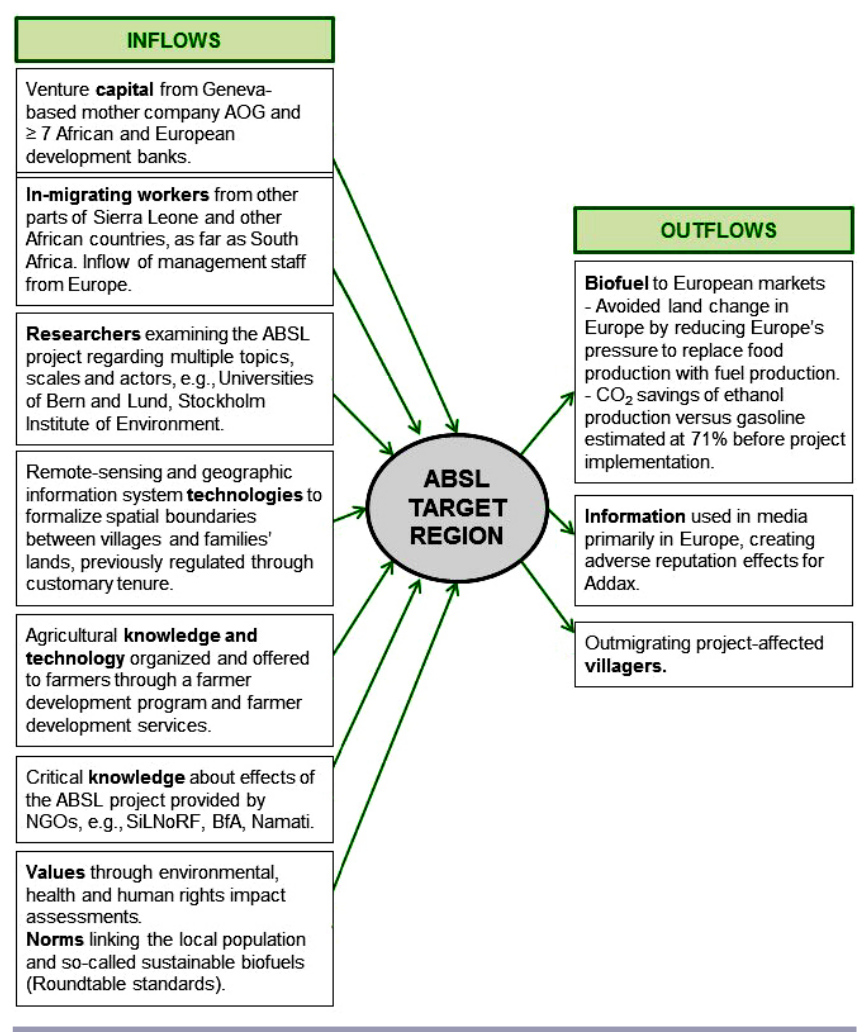

First, the setup phase of the ABSL project reinforced procedural inequality (arrow 1 in Fig. 5). Paramount chiefs and a set of male, elderly members of landowning families were privileged as community actors in the negotiation of the land lease and acknowledgement agreements. By contrast, women, young men, members of "stranger families" who had lived in the area for decades or generations, and other local land tenants were given fewer opportunities for making their voices heard in consultation processes.

A set of factors explains this procedural inequality. Numerous meetings were held in affected villages prior to the land deal, but they were largely informational, with limited space for critical voices or even negotiations of land leases. Parties to the locally reached agreements were ABSL, paramount chiefs, and male, elderly representatives of landowning families. Agreement documents were written in English even though illiteracy in the affected villages is high. Villagers' capacity to negotiate was 
Table 2. Applying the diagnostic procedure to the ABSL case (steps 1-4 and 6). Note: The results of steps 5 and 7 are shown in Figures 4 and 5, respectively.

\begin{tabular}{ll}
\hline \hline Step & Question \\
\hline 1 & What are the sustainability challenges in question? \\
& Reinforced inequalities within local communities and increased interlineage, interfamily, intervillage, and intergenerational tensions (capture of \\
& benefits by landowners and marginalization of tenants; Bottazzi et al. 2016, Millar 2016b). \\
& Impacts on livelihoods, varying between project-affected people and between indicators (access to natural resources, health, financial income, \\
& food security, infrastructure, extent of physical and economic displacement; Knoblauch et al. 2014, Fielding et al. 2015, Yengoh et al. 2015a, $b$, \\
& Marfurt et al. 2016, Millar 2016a, Bottazzi et al., in press). \\
& Reduced livelihood resilience due to loss of access to natural resources (e.g., oil palms), increased dependence on financial income and \\
& functioning local markets, dependence on one large-scale investment project, labor scarcity during growing and harvesting seasons, and reduced \\
& adaptability of newly formalized land rights (Fielding et al. 2015, Marfurt et al. 2016, Millar 2016a,b) \\
& Economic downturn of project operations in 2015 (SiLNoRF and BfA 2016).
\end{tabular}

Unclear effects on biodiversity, water quality and quantity, and carbon stocks (Fielding et al. 2015).

$2 \quad$ What actors hold stakes in which resources in the focal SES?

Main actors: Addax management; employees; mother company Addax and Oryx Group; development finance institutions; heterogenous local actors (e.g., paramount chiefs, subchiefs, landowning families, land tenants, stranger families, men/women, youth/elders, in-migrating laborers); national and district state actors; local and international NGOs (e.g., SiLNoRF, Bread for All, Namati); journalists; research organizations (e.g., Universities of Makeni, Bern, and Lund, Stockholm Environment Institute; Knoblauch et al. 2014, Bürgi 2015, Fielding et al. 2015, Yengoh et al. 2015a,b, Bottazzi et al. 2016, Marfurt et al. 2016, Millar 2016a,b, SiLNoRF and BfA 2016, Bottazzi et al., in press).

Main natural resources: landscape, water, soil, oil palms, vegetation, livestock, sugarcane, energy.

3 What ecological processes affect natural resources and ecosystem services with respect to the sustainability challenges identified in step 1 ? Dry season (Nov-Mar) with less than $20 \mathrm{~mm} / \mathrm{month}$ of rainfall requires irrigation of sugarcane; estimated 80 million $\mathrm{m}^{3}$ drawn from the Rokhel river (Manley et al. 2011).

Natural flow of some water streams is incompatible with the location of irrigation pivots; rebuilding of streams (Marfurt et al. 2016).

Risk of contamination of aquatic environments by nutrients and pest control agents (Manley et al. 2011).

Wetlands, terrestrial/village forest, and riparian forests rated as highly sensitive; avoidance of locating pivots in those areas (Manley et al. 2011).

Areas to be cleared carry carbon stocks generally lower than $30 \mathrm{t}$ of carbon per ha (Manley et al. 2011).

Biofuel production generates useful side products: bagasse as boiler fuel and vinasse as fertilizer (Manley et al. 2011).

4 What main institutional arrangements regulate the focal SES (Knoblauch et al. 2014, Bürgi 2015, Fielding et al. 2015, Marfurt et al. 2016)? Customary land tenure in Temne society: mostly family-based.

The public policy framework of Sierra Leone is linked to the customary law system through paramount chiefs and elected municipal officials. Project-related arrangements, including memorandum of understanding, land lease agreements, acknowledgement agreements.

National regulation of tax and duty exemptions for ABSL.

Code of Human Rights.

$5 \quad$ Flow-centered governance arrangements:

Rules and regulations of international development finance organizations and Roundtable on Sustainable Biofuels principles and indicators. Multi- and bilateral treaties for investment protection.

6 How do ecological, socioeconomic, and institutional factors (static or dynamic) shape interactions and outcomes in distant action situations, including the connecting flows?

Growing demand for biofuels from the EU.

EU institutional biofuel regime, including the European Commission's Renewable Energy Directive.

What effects do flows between the focal and distant regions have in the distant regions?

Reduced pressure to use land for energy production in the EU.

further limited because they had virtually no experience with longterm formal contracts and agribusiness, and many villagers were not fully aware of their legal rights and obligations. ABSL received support from the president of Sierra Leone, who is of the same Temne ethnicity as project-affected people, and respected local authorities. Both sources of support created trust among affected land users in the rightfulness of the land deal. Finally, ABSL's practice complied with the standards on community inclusion embodied in transnational regulations (Fiedling et al. 2015, Bottazzi et al. 2016).

Second, project implementation increased distributional and procedural inequalities within communities, accentuating asymmetries in the recognition of rights to access benefits of the biofuel project, including land lease payments and employment (arrow 2). Lease payments of US\$7.90 per hectare and year were paid directly to landowning families. This reinforced the status and power of landowners because there was no specific rule for redistributing these benefits to other land tenants who had lost access to land. The terms of employment affected inequalities between the genders and generations. The biofuel project created 3455 jobs as of December 2014, and about $38 \%$ of households in the villages had at least one member employed (Fielding et al. 2015). Even though reduced access to oil palms, vegetable gardens, firewood, and medicinal plants affected women in particular 
Fig. 5. Network of action situations and land system performance in the Addax Bioenergy in Sierra Leone (ABSL) case. Source: Authors. Abbreviations: RSB: Roundtable on Sustainable Biofuels, CDM: Clean Development Mechanism, DFI: Development Finance Institutions.

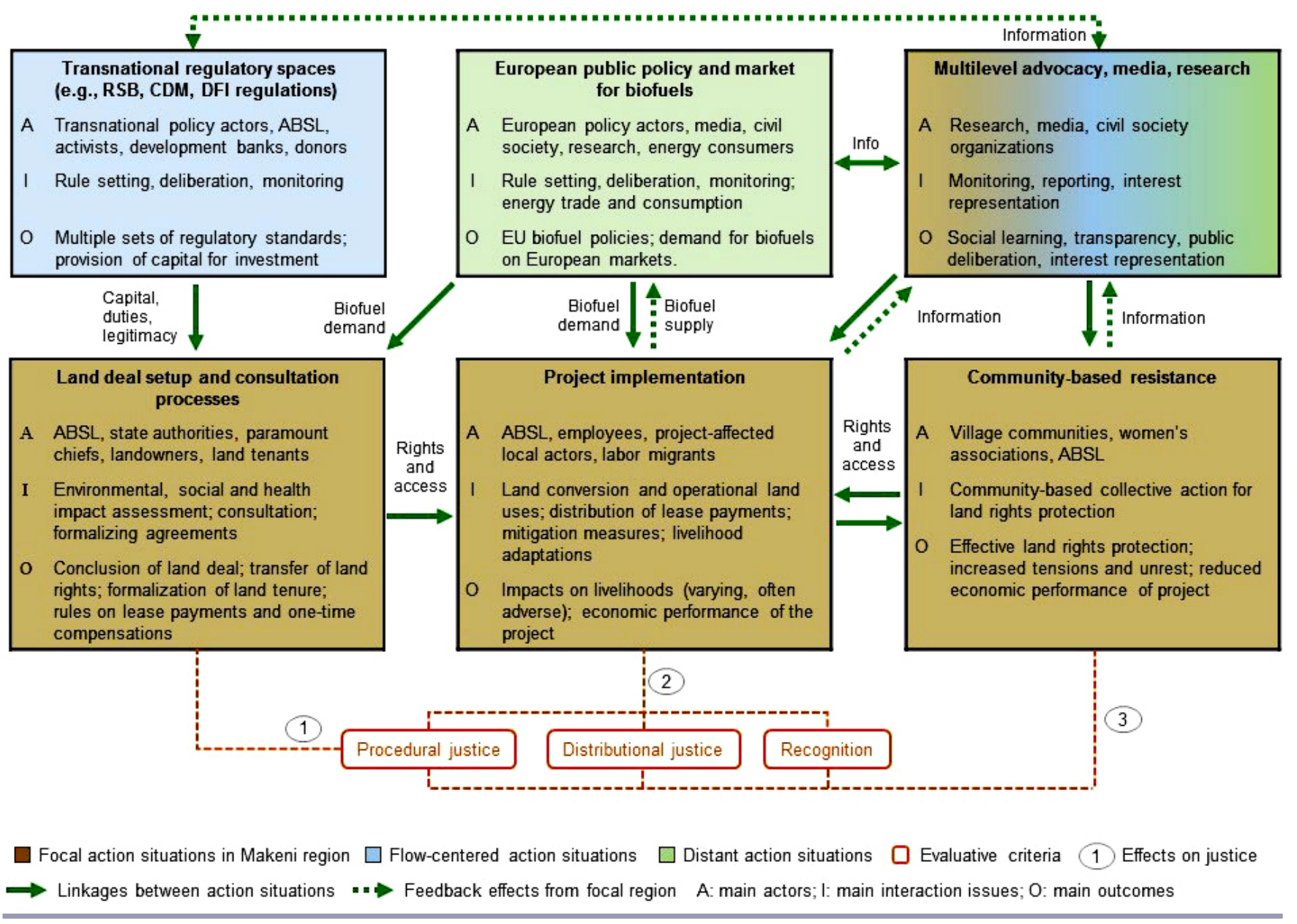

(Yengoh et al. 2015, Marfurt et al. 2016), only $10 \%$ of ABSL employees were women (Fielding et al. 2015). The demand for jobs exceeded their availability also among young men. Although the older generations lost, often in exchange for monetary compensation, some of their ability to provide access to natural resources for the young, the young generation had difficulties finding employment because ABSL considered their levels of education and skills to be insufficient for many jobs and preferred to employ in-migrants (Bottazzi et al. 2016, Millar 2016b).

Several factors account for this increase in inequality during project implementation. The customary land rights system had ensured that both landowners and land tenants could access land. The lease payment rules crafted in the land deal setup did not ensure access of nonlandowning families, women, and young people to the monetized benefits of land in a similar way. ABSL's literal interpretation of landownership, when implementing the transnational standards, did not take account of the traditional custom that nonlandowning families received access to land if they met specific conditions such as offering presents to landowners. The privileged role of landowners in the project's "community involvement" also accentuated asymmetries in costs and benefits arising from the specific placement of irrigation pivots. Furthermore, the international standards that ABSL followed did not ensure that women were adequately compensated for reduced access to traditional resources, e.g., oil palms or vegetable gardens, with access to new resources, e.g., jobs (Fielding et al. 2015, Marfurt et al. 2016).

In sum, these implications of the ABSL project for communitylevel inequality arose directly from interactions in the land deal setup and project implementation, which are shaped by distant and flow-centered action situations. A main effect of the reinforced inequalities is the emergence of new tensions between villages, lineages, and generations, as well as between locals and in-migrants in a historical context of civil war and persistent poverty (Bottazzi et al. 2016). The economic performance of the biofuel project was also adversely affected by instances of theft, increased security expenditures, and community-based resistance.

\section{Two transformative approaches to sustainability challenges and} their effects

This section analyzes two transformative approaches adopted in the ABSL case to tackle sustainability challenges. The NAS in 
Figure 5 helps to locate these initiatives and to analyze their interactions and effects within the overall system.

The first approach consists in the sustainability standards of the Roundtable on Sustainable Biofuels (RSB), which are located in the action situation of transnational regulatory spaces. ABSL made great efforts to comply with the RSB standards, commissioning extensive environmental, social, and health impact assessments and conducting consultation processes in the setup phase, followed by impact mitigation measures during project implementation. Addax obtained RSB certification in 2013 and was praised as a best practice example for sustainable biofuel production both in transnational spaces and in the EU.

However, this could not prevent the project's economic downscaling as of 2015. Furthermore, the application of transnational standards did not prevent adverse local impacts, particularly the reinforced inequalities and adverse livelihood impacts among the large group of those who lost access to natural resources without gaining the benefits of employment.

Interactions in the two local action situations partly explain these limitations of the RSB standards. In the setup phase, the RSB standards lacked sensitivity to varying local perceptions and the complexity of local power relations and access regimes. As noted above, the design of the consultation processes reinforced local power asymmetries by privileging male, elderly members of landowning families in the land lease and acknowledgement agreements. When implementing RSB principle 12 on "respect for land rights," landownership was interpreted literally, without taking into account traditional mechanisms of resource access for women, young men, and stranger families (Bottazzi et al. 2016). During project implementation, the mitigation measures, especially the farmer development program, proved less productive than expected and failed to become self-sustaining. This was partly due to a misconception of development; local people regarded the program as a compensation for the loss of land, whereas the company viewed it as a means of initiating technology and knowledge transfer and expected locals to adopt innovations within three years. Hence, stronger emphasis on justice and stronger feedback through information flows and learning from on-the-ground implementation could further refine the standards.

The second set of initiatives to tackle sustainability challenges is community-based collective action in affected villages (third local action situation in Fig. 5). Disappointment in the farmer development program mixed with growing perceptions among villagers that ABSL "broke their promises." This dissatisfaction triggered forms of community-based resistance. For example, in one village women self-organized to protect their land use rights, while a group of landowners did so in another village (Marfurt et al. 2016).

Community-based resistance has been effective in protecting access to land in these two instances, but it did not settle conflicts. The following reasons partly explain this performance. In the setup phase, new development visions and support by the highly respected president and local authorities sparked widespread optimism among affected land users. ABSL was unable to fulfil the high expectations regarding jobs and well-being of many local people. Support from local and international nongovernmental organizations such as Sierra Leone Network on the Right to Food, Bread for All, and Namati provided critical resources for resistance, including legal knowledge, social networks, and language skills. In the case of women's resistance noted above, women cooperated with male land users to convince local landowners of their perspective, thereby forming coalitions of those who were unwilling to accept ABSL's expansion plans. These initiatives of community-based resistance succeeded in protecting landowner' land rights and land tenants' informal access. Thereby, they limited further reproduction of inequality (arrow 3 in Fig. 5). However, their success also sparked severe accusations from ABSL and exacerbated tensions between local beneficiaries and losers of the investment (Bottazzi et al. 2016, Millar 2016b). Furthermore, it was one factor in reducing the project's economic performance by impeding the installation of specific new irrigation pivots (Fielding et al. 2015, Marfurt et al. 2016).

\section{DISCUSSION AND CONCLUSION}

Polycentric governance in telecoupled resource systems

This paper has linked and operationalized the analysis of polycentric governance and telecoupled systems by using the approach of networks of action situations (NAS). The ABSL case has illustrated how analysis of NAS can identify interactions in polycentric governance systems as drivers of sustainability problems in telecoupled systems and how it can analyze the scope for transformative change toward more sustainable development within polycentric systems.

The global land rush is a paradigmatic trend toward greater telecoupling of land systems. Over the past decade, large-scale land acquisitions (LSLAs) have created a widespread network of intra- and transnational capital flows and associated land rights relations (Nolte et al. 2016). They also triggered new flows of ideas, raw materials, commodities, and human migration (Margulis et al. 2013, Zoomers et al. 2016). The majority of LSLAs target crops with flexible uses for food, fuel, feed, or industry such as soy, sugarcane, oil palm, and corn (Nolte et al. 2016). Such flex crops "have multiple uses (...) that can be flexibly interchanged while some consequent supply gaps can be filled by other flex crops" (Borras et al. 2016:94). Flex crops provide agricultural producers with access to multiple value chains (Oliveira and Schneider 2016). The stages of value chains from production, processing, circulation to consumption are hence multiplying into "value webs" with adaptable flows of commodities (Borras et al. 2016).

The global land rush and the rise of flex crops illustrate some of the major governance challenges of telecoupling to sustainability. First, the rise of flex crops intensifies the dynamic telecoupling of regions through value webs. Single or uncoordinated centers of governing power reach limitations for regulating highly adaptable commodity flows (Borras et al. 2016). A polycentric approach to governance in telecoupled systems asks how transnational governance mechanisms, national and subnational public regulatory spaces, private and hybrid standards, as well as community-based self-organization can be linked to shape telecoupled systems in view of sustainability.

Second, the land use dynamics in target regions of LSLAs are strongly shaped by investors, governments, and consumers from 
distant regions. LSLA also created new ecological interconnectedness through enhanced virtual water trade (Breu et al. 2016), agrochemical pollution of water resources (Dell'Angelo et al. 2017b), and by contributing to climate change by reducing soil organic carbon (Shete et al. 2016). This spatial separation of decision making from land use change is prone to unintended social and ecological consequences (Eakin et al. 2014, Liu et al. 2015). It creates new trade-offs and conflicts of interest between local and distant users of land resources, and their negotiations are conducted and shaped through interactions in multiple linked governance spaces.

Third, the global land rush generates new configurations of power in land governance (Margulis et al. 2013). ABSL's investment, for instance, implied the emergence of a strong actor in the target region, who could mobilize financial capital, support by governmental and customary authorities, as well as technology to gain and maintain access to land in Sierra Leone. The reinforced inequalities in the ABSL case illustrate that polycentric governance with pronounced power differentials is not necessarily fair and just (Su et al. 2017).

The NAS approach is one tool to analyze strategies for transformations toward more just or sustainable development in polycentric and telecoupled systems. Since 2008, many governance responses to the global land rush emerged. They occur in a suite of social spaces and places rather than in one single institution (Margulis et al. 2013), ranging from state regulations, private standards, hybrid mechanisms, community-based resistance to transnational social movements (Hall et al. 2015, Pacheco et al. 2017). The effects of one initiative typically depend on polycentric interplay with others (Young et al. 2008). For instance, Burnod et al. (2013) show how a Malagasy community was able to self-organize and protect its land rights by forming coalitions with a like-minded state department, which successfully competed with another LSLA-friendly state department. By contrast, this community-based strategy is unlikely to protect land rights, if community leaders or the strongest forces within government prioritize LSLA for development (Wolford et al. 2013, Oberlack et al. 2016). Seufert (2013) argues that the transnational Voluntary Guidelines of Responsible Governance of Tenure (VGGT) helped raise awareness and offer practical guidance to governments, companies, and civil society; but their effectiveness for tenure security depends on mechanisms within states to hold decision makers accountable to the VGGT standards.

Thus, transformative strategies in the global land rush, and telecoupled systems more generally, need to be understood in the context of linked governance spaces. Such analysis allows one to disentangle the tight interdependency of actors in telecoupled systems, which arises not only from coupled social and ecological processes but also from connectedness of systems across distance creating coupled risks and opportunities (Galaz 2014).

\section{Methodological reflection}

The delineation of boundaries of action situations is an important task in applying the NAS approach. We have identified six analytical strategies from earlier NAS applications, as described in the section "A diagnostic procedure" above. Here we reflect on our application of NAS for analyzing the ABSL case.
First, is it useful to think about action situations as having a temporal imprint, i.e., can they be activated and terminated over time? Polycentricity is often implicitly portrayed as a static attribute of governance systems despite its dynamic character (Galaz et al. 2012). To conceive action situations as having a temporal imprint allows analyzing the evolution of interactions in polycentric governance systems over time, including the emergence of new governance spaces and the termination of others (Morrison 2017). In our ABSL analysis, the "land deal setup" action situation is terminated after agreements are concluded, and the "project implementation" starts with initial land conversion (Fig. 5). There is small temporal overlap of both (Fig. 3). We conceive these analytical boundaries as appropriate, because the involved actors, their interaction issues, and the outcomes are markedly different between both situations (Fig. 5). Even more importantly, the outcome of interest in our analysis, reinforced community inequalities, is shaped by two different mechanisms - voice in consultations and negotiations vs. access to compensation payments and employment-in the two situations.

Second, is it useful to group diverse transnational regulations and EU policy and markets into one action situation each and to differentiate community-based resistance from project implementation? Interactions in the Roundtable for Sustainable Biofuels are different from those in the African Development Bank or other development finance institutes. We made this analytical choice not differentiating them here in view of the outcome of interest, i.e., reinforced community inequalities. Both our own research and other publications on the case did not show a differential effect of different transnational regulations on community-level inequalities. The main effect is one of shaping ABSL's behavior in the land deal setup. By contrast, community-based resistance did affect community-level inequalities differently than the overall project implementation. Resistance initiatives were able to limit inequalities, which were created in project implementation.

In sum, there are multiple options for delineating boundaries of action situations. The most appropriate delineation is a result of the analysis rather than an a priori definition (Friis and Nielsen 2017). Our criterion to assess this appropriateness is the explanatory power for the outcome of interest in question.

\section{Outlook}

We linked a place-based understanding of land use change in the perimeter of ABSL's investment in the Makeni region of Sierra Leone with the process-based analysis of flows and governance in six local, distant, and flow-centered action situations to explain why the investment increased community-level inequalities. Future research can expand this by analyzing the precise features of polycentric systems that account for varying levels of justice in telecoupled settings. This may benefit from analyzing the causes and consequences of power differentials in land governance. Finally, future research is needed to advance understanding of actor agency for innovations, which create new action situations by linking new configurations of actors, resources, and governance issues to shape land use and the sustainability of distantly connected land systems. 
Responses to this article can be read online at: http://www.ecologyandsociety.org/issues/responses. php/9902

\section{Acknowledgments:}

We are grateful for helpful comments by Christian Kimmich, the reviewers, and editors; for language editing by Marlène Thibault; and for research assistance by Patrick Kupferschmied and Andrea Winiger. We gratefully acknowledge financial support from the University of Bern, Institute of Geography (research cluster "Governing telecoupled resource systems for environmental justice”), and from the Swiss National Science Foundation (project ATLAS, grant number 406840_161905, and R4D project “Telecoupled Landscapes,” grant number SNSF 400440-152167).

\section{LITERATURE CITED}

Addax Oryx Group (AOG). 2016. AOG transfers ownership of pioneering bioethanol and green electricity operation in Sierra Leone. Press release. [online] URL: http://www.sunbirdbioenergy. com/2016/09/30/aog-transfers-ownership-of-pioneering-bioethanoland-green-electricity-operation-in-sierra-leone-to-sunbird-bioenergy/

Agrawal, A. 2001. Common property institutions and sustainable governance of resources. World Development 29:1649-1672. http://dx.doi.org/10.1016/S0305-750X(01)00063-8

Agyeman, J., D. Schlosberg, L. Craven, and C. Matthews. 2016. Trends and directions in environmental justice: from inequity to everyday life, community, and just sustainabilities. Annual Review of Environment and Resources 41:321-340. http://dx.doi. org/10.1146/annurev-environ-110615-090052

Aligica, P. D., and V. Tarko. 2012. Polycentricity: from Polanyi to Ostrom, and beyond. Governance 25(2):237-262. http://dx.doi. org/10.1111/j.1468-0491.2011.01550.X

Anane, M., and C. Y. Abiwu. 2011. Independent study report of the Addax bioenergy sugarcane-to-ethanol project in the Makeni Region in Sierra Leone. Sierra Leone Network on the Right to Food (SiLNoRF), Bread for All, Bern, Switzerland, Bread for the World and Evangelischer Entwicklungsdienst (EED), Bonn, Germany.

Anderies, J. M., and M. A. Janssen. 2011. The fragility of robust social-ecological systems. Global Environmental Change 21:1153-1156. http://dx.doi.org/10.1016/j.gloenvcha.2011.07.004

Ångström A. 1935. Teleconnections of climate changes in present time. Geografiska Annaler 17:242-258. http://dx.doi.org/10.2307/519964

Berkes, F. 2007. Community-based conservation in a globalized world. Proceedings of the National Academy of Sciences 104 (39):15188-15193. http://dx.doi.org/10.1073/pnas.0702098104

Biermann, F. 2014. Earth system governance: world politics in the Anthropocene. MIT Press, Cambridge, Massachusetts, USA. http://dx.doi.org/10.7551/mitpress/9780262028226.001.0001

Biggs, R., M. Schlüter, D. Biggs, E. L. Bohensky, B. BurnSilver, G. Cundill, V. Dakos, T. M. Daw, L. S. Evans, K. Kotschy, A. M. Leitch, C. Meek, A. Quinlan, C. Raudsepp-Hearne, M. D.
Robards, M. L. Schoon, L. Schultz, and P. C. West. 2012. Toward principles for enhancing the resilience of ecosystem services. Annual Review of Environment and Resources 37:421-448. http:// dx.doi.org/10.1146/annurev-environ-051211-123836

Borras, S. M., J. C. Franco, S. R. Isakson, L. Levidow, and P. Vervest. 2016. The rise of flex crops and commodities: implications for research. Journal of Peasant Studies 43(1):93-115. http://dx.doi.org/10.1080/03066150.2015.1036417

Bottazzi, P., D. Crespo, L. O. Bangura, and S. Rist. In press. Evaluating the livelihood impacts of a large-scale agricultural investment: lessons from the case of a biofuel production company in northern Sierra Leone. Land Use Policy.

Bottazzi, P., A. Goguen, and S. Rist. 2016. Conflicts of customary land tenure in rural Africa: is large-scale land acquisition a driver of 'institutional innovation'? Journal of Peasant Studies 43 (5):971-988. http://dx.doi.org/10.1080/03066150.2015.1119119

Breu, T., C. Bader, P. Messerli, A. Heinimann, S. Rist, and S. Eckert. 2016. Large-scale land acquisition and its effects on the water balance in investor and host countries. PLOS ONE 11(3): e0150901. http://dx.doi.org/10.1371/journal.pone.0150901

Brondizio, E. S., E. Ostrom, and O. R. Young. 2009. Connectivity and the governance of multilevel social-ecological systems: the role of social capital. Annual Review of Environment and Resources 34:253-278. http://dx.doi.org/10.1146/annurev.environ.020708.100707

Bürgi, E. 2015. Sustainable investment in land in the Global South: what would it require from a coherence perspective? The case of Sierra Leone. Questions of International Law 21:17-37.

Burnod, P., M. Gingembre, and R. Andrianirina Ratsialonana. 2013. Competition over authority and access: international land deals in Madagascar. Development and Change 44(2):357-379. http://dx.doi.org/10.1111/dech.12015

Carlisle, K., and R. L. Gruby. 2017. Polycentric systems of governance: a theoretical model for the commons. Policy Studies Journal. http://dx.doi.org/10.1111/psj.12212

Challies, E., J. Newig, and A. Lenschow. 2014. What role for social-ecological systems research in governing global teleconnections? Global Environmental Change 27:32-40. http:// dx.doi.org/10.1016/j.gloenvcha.2014.04.015

Cox, M. 2014a. Understanding large social-ecological systems: introducing the SESMAD project. International Journal of the Commons 8(2):265-276. http://dx.doi.org/10.18352/ijc.406

Cox, M. 2014b. Modern disturbances to a long-lasting community-based resource management system: the Taos Valley acequias. Global Environmental Change 24:213-222. http://dx.doi. org/10.1016/j.gloenvcha.2013.12.006

Cox, M., G. Arnold, and S. Villamayor-Tomás. 2010. A review of design principles for community-based natural resource management. Ecology and Society 15(4):38. http://dx.doi. org/10.5751/ES-03704-150438

Dell'Angelo, J., P. D’Odorico, and M. C. Rulli. 2017b. Threats to sustainable development posed by land and water grabbing. Current Opinion in Environmental Sustainability 26-27:120-128. http://dx.doi.org/10.1016/j.cosust.2017.07.007 
Dell'Angelo, J., P. D'Odorico, M. C. Rulli, and P. Marchand. 2017a. The tragedy of the grabbed commons: coercion and dispossession in the global land rush. World Development 92:1-12. http://dx.doi.org/10.1016/j.worlddev.2016.11.005

Dietz, T., E. Ostrom, and P. C. Stern. 2003. The struggle to govern the commons. Science 302:1907-1912. http://dx.doi.org/10.1126/ science.1091015

Duit, A., and V. Galaz. 2008. Governance and complexityemerging issues for governance theory. Governance 21(3):311-335. http://dx.doi.org/10.1111/j.1468-0491.2008.00402.x

Eakin, H., R. DeFries, S. Kerr, E. F. Lambin, J. Liu, P. J. Marcotullio, P. Messerli, A. Reenberg, X. Rueda, S. R. Swaffield, B. Wicke, and K. Zimmerer. 2014. Significance of telecoupling for exploration of land-use change. Pages 141-161 in K. C. Seto and A. Reenberg, editors. Rethinking global land use in an urban era. Strüngmann Forum Reports, Vol. 14. MIT Press, Cambridge, Massachusetts, USA. http://dx.doi.org/10.7551/mitpress/97802$\underline{62026901.003 .0008}$

Fielding, M., M. Davis, N. Weitz, I. Cummings-John, A. Hickey, F. Johnson, J. Senyagwa, L. Martinez, and M. Sun. 2015. Agricultural investment and rural transformation: a case study of the Makeni bioenergy project in Sierra Leone. Project Report 2015-09. Stockholm Environment Institute, Stockholm, Sweden. [online] URL: https://www.sei-international.org/mediamanager/ documents/Publications/Climate/SEI-PR-2015-09-Makeni-ProjectES.pdf

Folke, C., T. Hahn, P. Olsson, and J. Norberg. 2005. Adaptive governance of social-ecological systems. Annual Review of Environment and Resources 30:441-473. http://dx.doi.org/10.1146/ annurev.energy.30.050504.144511

Friis, C., and J. Ø. Nielsen. 2017. On the system. Boundary choices, implications, and solutions in telecoupling land use change research. Sustainability 9(6):974. http://dx.doi.org/10.3390/ $\underline{\text { su9060974 }}$

Friis, C., J. Ø. Nielsen, I. Otero, H. Haberl, J. Niewöhner, and P. Hostert. 2016. From teleconnection to telecoupling: taking stock of an emerging framework in land system science. Journal of Land Use Science 11(2):131-153. http://dx.doi.org/10.1080/1747423X.2015 .1096423

Galaz, V. 2014. Global environmental governance, technology and politics: the Anthropocene gap. Edward Elgar, Cheltenham, UK. http://dx.doi.org/10.4337/9781781955550

Galaz, V., B. Crona, H. Österblom, P. Olsson, and C. Folke. 2012. Polycentric systems and interacting planetary boundaries: emerging governance of climate change-ocean acidificationmarine biodiversity. Ecological Economics 81:21-32. http://dx. doi.org/10.1016/j.ecolecon.2011.11.012

Gerber, J. D., P. Knoepfel, S. Nahrath, and F. Varone. 2009. Institutional resource regimes: towards sustainability through the combination of property-rights theory and policy analysis. Ecological Economics 68(3):798-809. http://dx.doi.org/10.1016/j. ecolecon.2008.06.013

Global Land Programme (GLP). 2005. GLP science plan and implementation strategy. IGBP Report No. 53. International Geosphere-Biosphere Programme, Stockholm, Sweden.
Global Land Programme (GLP). 2016. Global Land Programme Science Plan and Implementation Strategy 2016-21. GLP, Universität Bern Centre for Development and Environment, Bern Switzerland. [online] URL: https://glp.earth/our-science/scienceplan

Grundmann, P., and M.-H. Ehlers. 2016. Determinants of courses of action in bioenergy villages responding to changes in renewable heat utilization policy. Utilities Policy 41:183-192. http://dx.doi. org/10.1016/j.jup.2016.02.012

Hall, R., M. Edelman, S. M. Borras, I. Scoones, B. White, and W. Wolford. 2015. Resistance, acquiescence or incorporation? An introduction to land grabbing and political reactions 'from below. ' Journal of Peasant Studies 42(3-4):467-488. http://dx.doi. org/10.1080/03066150.2015.1036746

Hinkel, J., M. E. Cox, M. Schlüter, C. R. Binder, and T. Falk. 2015. A diagnostic procedure for applying the social-ecological systems framework in diverse cases. Ecology and Society 20(1):32. http://dx.doi.org/10.5751/ES-07023-200132

Hooghe, L., and G. Marks. 2003. Unraveling the central state, but how? Types of multi-level governance. American Political Science Review 97(02):233-243.

Hufty, M. 2011. Investigating policy processes: the governance analytical framework (GAF). Pages 403-424 in U. Wiesmann and H. Hurni, editors. Research for sustainable development: foundations, experiences, and perspectives. Geographica Bernensia, Bern, Switzerland.

Kimmich, C. 2013. Linking action situations: coordination, conflicts, and evolution in electricity provision for irrigation in Andhra Pradesh, India. Ecological Economics 90:150-158. http:// dx.doi.org/10.1016/j.ecolecon.2013.03.017

Kimmich, C., and S. Villamayor-Tomás. 2018. Assessing action situation networks: a configurational perspective on water and energy governance in irrigation systems. Water Economics and Policy. http://dx.doi.org/10.1142/S2382624X18500054

Knoblauch, A. M., M. H. Hodges, M. S. Bah, H. I. Kamara, A. Kargbo, J. Paye, H. Turay, E. D. Nyorkor, M. J. Divall, Y. Zhang, J. Utzinger, and M. S. Winkler. 2014. Changing patterns of health in communities impacted by a bioenergy project in northern Sierra Leone. International Journal of Environmental Research and Public Health 11(12):12997-13016. http://dx.doi.org/10.3390/ ijerph111212997

Knüppe, K., and C. Knieper. 2016. The governance of ecosystem services in river basins: an approach for structured data representation and analysis. Environmental Science \& Policy 66:31-39. http://dx.doi.org/10.1016/j.envsci.2016.07.009

Lambin, E. F., and P. Meyfroidt. 2011. Global land use change, economic globalization, and the looming land scarcity Proceedings of the National Academy of Sciences 108 (9):3465-3472. http://dx.doi.org/10.1073/pnas.1100480108

Lenschow, A., J. Newig, and E. Challies. 2016. Globalization's limits to the environmental state? Integrating telecoupling into global environmental governance. Environmental Politics 25 (1):136-159. http://dx.doi.org/10.1080/09644016.2015.1074384 
Liu, J. 2014. Forest sustainability in China and implications for a telecoupled world. Asia \& the Pacific Policy Studies 1(1):230-250. http://dx.doi.org/10.1002/app5.17

Liu, J., V. Hull, M. Batistella, R. DeFries, T. Dietz, F. Fu, T. W. Hertel, R. C. Izaurralde, E. F. Lambin, S. Li, L. A. Martinelli, W. J. McConnell, E. F. Moran, R. Naylor, Z. Ouyang, K. R. Polenske, A. Reenberg, G. de Miranda Rocha, C. S. Simmons, P. H. Verburg, P. M. Vitousek, F. Zhang, and C. Zhu. 2013. Framing sustainability in a telecoupled world. Ecology and Society 18 (2):26. http://dx.doi.org/10.5751/ES-05873-180226

Liu, J., V. Hull, J. Luo, W. Yang, W. Liu, A. Viña, C. Vogt, Z. Xu, H. Yang, J. Zhang, L. An, X. Chen, S. Li, Z. Ouyang, W. Xu, and H. Zhang. 2015. Multiple telecouplings and their complex interrelationships. Ecology and Society 20(3):44. http://dx.doi. org/10.5751/ES-07868-200344

Lubell, M. 2013. Governing institutional complexity: the ecology of games framework. Policy Studies Journal 41(3):537-559. http:// dx.doi.org/10.1111/psj.12028

Manley, G., K. Lonsway, R. Aron, M. Niang, T. Turner, and F. Perrault. 2011. Executive summary of the environmental, social and health impact assessment of the Addax Bioenergy Project, Sierra Leone. African Development Bank, Paris, France. [online] URL: https://www.afdb.org/fileadmin/uploads/afdb/Documents/ Environmental-and-Social-Assessments/Addax $\% 20$ Bioenergy $\% 20$ $\% 20$ ESHIA $\% 20$ summary $\% 20-\% 20$ Final $\% 20$ EN.pdf

Mann, S. 2016. Governing complementary responsibility goods through hybrid systems in a globalizing world. Journal of SocioEconomics in Agriculture 9:14-21.

Mann, S., and E. Bürgi-Bonanomi. 2017. Grabbing or investment? On judging large-scale land acquisitions. Agriculture and Human Values 34:41-51. http://dx.doi.org/10.1007/s10460-016-9688-1

Marfurt, F., F. Käser, and S. Lustenberger. 2016. Local perceptions and vertical perspectives of a large scale land acquisition project in Northern Sierra Leone. Homo Oeconomicus 33(3):261-279. http://dx.doi.org/10.1007/s41412-016-0020-5

Margulis, M. E., N. McKeon, and S. M. Borras. 2013. Land grabbing and global governance: critical perspectives. Globalizations 10(1):1-23. http://dx.doi.org/10.1080/14747731.2$\underline{013.764151}$

McGinnis, M. D., editor. 1999. Polycentric governance and development: readings from the Workshop in Political Theory and Policy Analysis. University of Michigan Press, Ann Arbor, Michigan, USA. http://dx.doi.org/10.3998/mpub.16052

McGinnis, M. D. 2011a. Networks of adjacent action situations in polycentric governance. Policy Studies Journal 39(1):51-78. http://dx.doi.org/10.1111/j.1541-0072.2010.00396.x

McGinnis, M. D. 2011b. An introduction to IAD and the language of the Ostrom workshop: a simple guide to a complex framework. Policy Studies Journal 39(1):169-183. http://dx.doi. org/10.1111/j.1541-0072.2010.00401.x

McGinnis, M. D., and E. Ostrom. 2014. Social-ecological system framework: initial changes and continuing challenges. Ecology and Society 19(2):30. http://dx.doi.org/10.5751/ES-06387-190230
Meyfroidt, P., E. F. Lambin, K.-H. Erb, and T. W. Hertel. 2013. Globalization of land use: distant drivers of land change and geographic displacement of land use. Current Opinion in Environmental Sustainability 5(5):438-444. http://dx.doi.org/10.1016/ j.cosust.2013.04.003

Millar, G., 2016a. Knowledge and control in the contemporary land rush: making local land legible and corporate power applicable in rural Sierra Leone. Journal of Agrarian Change 16 (2):206-224. http://dx.doi.org/10.1111/joac.12102

Millar, G. 2016b. Local experiences of liberal peace: marketization and emergent conflict dynamics in Sierra Leone. Journal of Peace Research 53(4):569-581. http://dx.doi. org/10.1177/0022343316632580

Morrison, T. H. 2017. Evolving polycentric governance of the Great Barrier Reef. Proceedings of the National Academy of Sciences 114(15):E3013-E3021. http://dx.doi.org/10.1073/ pnas. 1620830114

Moser, S. C., and J. A. F. Hart. 2015. The long arm of climate change: societal teleconnections and the future of climate change impacts studies. Climatic Change 129(1-2):13-26. http://dx.doi. org/10.1007/s10584-015-1328-Z

Nagendra, H., and E. Ostrom. 2012. Polycentric governance of multifunctional forested landscapes. International Journal of the Commons 6(2):104-133. http://dx.doi.org/10.18352/ijc.321

Nolte, K., W. Chamberlain, and M. Giger. 2016. International land deals for agriculture. Fresh insights from the Land Matrix: Analytical Report II. Centre for Development and Environment, University of Bern; Centre de coopération internationale en recherche agronomique pour le développement; German Institute of Global and Area Studies; University of Pretoria; Bern Open Publishing.

Oberlack, C., L. Tejada, P. Messerli, S. Rist, and M. Giger. 2016. Sustainable livelihoods in the global land rush? Archetypes of livelihood vulnerability and sustainability potentials. Global Environmental Change 41:153-171. http://dx.doi.org/10.1016/j. gloenvcha.2016.10.001

Oliveira, G. D. L. T., and M. Schneider. 2016. The politics of flexing soybeans: China, Brazil and global agroindustrial restructuring. Journal of Peasant Studies 43(1):167-194. http://dx. doi.org/10.1080/03066150.2014.993625

Osberghaus, D., A. Dannenberg, T. Mennel, and B. Sturm. 2010. The role of the government in adaptation to climate change. Environment and Planning C: Government and Policy 28:834-850. http://dx.doi.org/10.1068/c09179j

Ostrom, E. 1990. Governing the commons: the evolution of institutions for collective action. Cambridge University Press, Cambridge, UK. http://dx.doi.org/10.1017/CBO9780511807763

Ostrom, E. 2005. Understanding institutional diversity. Princeton University Press, Princeton, New Jersey, USA.

Ostrom, E. 2009. A general framework for analyzing sustainability of social-ecological systems. Science 325:419-422. http://dx.doi.org/10.1126/science.1172133 
Ostrom, E. 2010. Beyond markets and states: polycentric governance of complex economic systems. American Economic Review 100:641-672. http://dx.doi.org/10.1257/aer.100.3.641

Ostrom, E. 2011. Background on the institutional analysis and development framework. Policy Studies Journal 39(1):7-27. http:// dx.doi.org/10.1111/j.1541-0072.2010.00394.X

Paavola, J. 2007. Institutions and environmental governance: a reconceptualization. Ecological Economics 63:93-103. http://dx. doi.org/10.1016/j.ecolecon.2006.09.026

Pacheco, P., G. C. Schoneveld, A. Dermawan, H. Komarudin, and M. Djama. 2017. The public and private regime complex for governing palm oil supply: what scope for building connections and enhancing complementarities? CIFOR Infobrief no. 174. Center for International Forestry Research, Bogor, Indonesia.

Pahl-Wostl, C., G. Holtz, B. Kastens, and C. Knieper. 2010. Analyzing complex water governance regimes: the management and transition framework. Environmental Science \& Policy 13 (7):571-581. http://dx.doi.org/10.1016/j.envsci.2010.08.006

Pahl-Wostl, C., and C. Knieper. 2014. The capacity of water governance to deal with the climate change adaptation challenge: using fuzzy set qualitative comparative analysis to distinguish between polycentric, fragmented and centralized regimes. Global Environmental Change 29:139-154. http://dx.doi.org/10.1016/j. gloenvcha.2014.09.003

Pahl-Wostl, C., L. Lebel, C. Knieper, and E. Nikitina. 2012. From applying panaceas to mastering complexity: toward adaptive water governance in basins. Environmental Science \& Policy 23:24-34. http://dx.doi.org/10.1016/j.envsci.2012.07.014

Pattberg, P. 2010. Public-private partnerships in global climate governance. Wiley Interdisciplinary Reviews: Climate Change 1 (2):279-287. http://dx.doi.org/10.1002/wcc.38

Reenberg, A. 2009. Land system science: handling complex series of natural and socio-economic processes. Journal of Land Use Science 4:1-4. http://dx.doi.org/10.1080/17474230802645618

Reinecke, S., T. Pistorius, and M. Pregernig. 2014. UNFCCC and the REDD+ Partnership from a networked governance perspective. Environmental Science \& Policy 35:30-39. http://dx. doi.org/10.1016/j.envsci.2012.09.015

Rounsevell, M. D. A., A. Arneth, D. G. Brown, N. de NobletDucoudré, J. Finnigan, K. Galvin, N. Grigg, I. Harman, J. Lennox, N. Magliocca, D. Parker, B. O’Neil, P. H. Verburg, and O. Young. 2012. Incorporating human behaviour and decision making processes in land use and climate system models. GLP Report No. 7. GLP International Project Office, São José dos Campos, Brazil.

Schlosberg, D. 2013. Theorising environmental justice: the expanding sphere of a discourse. Environmental Politics 22 (1):37-55. http://dx.doi.org/10.1080/09644016.2013.755387

Schlüter, M., D. Hirsch, and C. Pahl-Wostl. 2010. Coping with change: responses of the Uzbek water management regime to socio-economic transition and global change. Environmental Science \& Policy 13(7):620-636. http://dx.doi.org/10.1016/j. envsci.2010.09.001
Seufert, P. 2013. The FAO voluntary guidelines on the responsible governance of tenure of land, fisheries and forests. Globalizations 10(1):181-186. http://dx.doi.org/10.1080/14747731.2013.764157

Shete, M., M. Rutten, G. C. Schoneveld, and E. Zewude. 2016. Land-use changes by large-scale plantations and their effects on soil organic carbon, micronutrients and bulk density: empirical evidence from Ethiopia. Agriculture and Human Values 33 (3):689-704. http://dx.doi.org/10.1007/s10460-015-9664-1

Sierra Leone Network on the Right to Food and Bread for All (SiLNoRF and BfA). 2016. Final monitoring report. On the operations and the scale down of Addax Bioenergy in Makeni, Sierra Leone. SiLNoRF, Sierra Leone and BfA, Bern, Switzerland. [online] URL: https://brotfueralle.ch/content/ uploads/2016/03/MonRep-Addax-2016.pdf

Sikor, T., G. Auld, A. J. Bebbington, T. A. Benjaminsen, B. S. Gentry, C. Hunsberger, A.-M. Izac, M. E. Margulis, T. Plieninger, H. Schroeder, and C. Upton. 2013. Global land governance: from territory to flow? Current Opinion in Environmental Sustainability 5(5):522-527. http://dx.doi.org/10.1016/j.cosust.2013.06.006

Su, S., Z. Liu, Y. Xu, J. Li, J. Pi, and M. Weng. 2017. China's megaregion policy: performance evaluation framework, empirical findings and implications for spatial polycentric governance. Land Use Policy 63:1-19. http://dx.doi.org/10.1016/ j.landusepol.2017.01.014

Thiel, A. 2016. The polycentricity approach and the research challenges confronting environmental governance. THESys Discussion Paper No. 2016-1. Humboldt-Universität zu Berlin, Berlin, Germany.

Thiel, A., and C. Egerton. 2011. Re-scaling of resource governance as institutional change: the case of water governance in Portugal. Journal of Environmental Planning and Management 54(3):383-402. http://dx.doi.org/10.1080/09640568.2010.507936

Turner, B. L., E. F. Lambin, and A. Reenberg. 2007. The emergence of land change science for global environmental change and sustainability. Proceedings of the National Academy of Sciences 104:20666-20671. http://dx.doi.org/10.1073/pnas.0704119104

Vatn, A. 2005. Institutions and the environment. Edward Elgar. Cheltenham, UK.

Verburg, P. H., N. Crossman, E. C. Ellis, A. Heinimann, P. Hostert, O. Mertz, H. Nagendra, T. Sikor, K.-H. Erb, N. Golubiewski, R. Grau, M. Grove, S. Konaté, P. Meyfroidt, D. C. Parker, R. R. Chowdhury, H. Shibata, A. Thomson, and L. Zhen. 2015. Land system science and sustainable development of the earth system: a global land project perspective. Anthropocene 12:29-41. http://dx.doi.org/10.1016/j.ancene.2015.09.004

Villamayor-Tomás, S. 2014. Cooperation in common property regimes under extreme drought conditions: empirical evidence from the use of pooled transferable quotas in Spanish irrigation systems. Ecological Economics 107:482-493. http://dx.doi. org/10.1016/j.ecolecon.2014.09.005

Villamayor-Tomás, S., P. Grundmann, G. Epstein, T. Evans, and C. Kimmich. 2015. The water-energy-food security nexus through the lenses of the value chain and IAD frameworks. Water Alternatives 8(1):735-755. 
Wiesmann, U., C. Ott, C. Ifejika Speranza, B. P. Kiteme, U. Müller-Böker, P. Messerli, and J. Zinsstag. 2011. A human actor model as a conceptual orientation in interdisciplinary research for sustainable development. Pages 231-256 in U. Wiesmann and H. Hurni, editors. Research for sustainable development: foundations, experiences, and perspectives. Perspectives of the Swiss National Centre of Competence in Research (NCCR) North-South, University of Bern, Vol. 6. Geographica Bernensia, Bern, Switzerland.

Wolford, W., S. M. Borras, R. Hall, I. Scoones, and B. White. 2013. Governing global land deals: the role of the state in the rush for land. Development and Change 44(2):189-210.

Yengoh, G. T., and F. A. Armah. 2015. Effects of large-scale acquisition on food insecurity in Sierra Leone. Sustainability 7 (7):9505-9539. http://dx.doi.org/10.3390/su7079505

Yengoh, G. T., F. A. Armah, and K. Steen. 2015. Women's bigger burden: disparities in outcomes of large scale land acquisition in Sierra Leone. Gender Issues 32(4):221-244. http://dx.doi. org/10.1007/s12147-015-9140-7

Yengoh, G. T., K. Steen, F. A. Armah, and B. Ness. 2016. Factors of vulnerability: how large-scale land acquisitions take advantage of local and national weaknesses in Sierra Leone. Land Use Policy 50:328-340. http://dx.doi.org/10.1016/j.landusepol.2015.09.028

Young, O. R., F. Berkhout, G. C. Gallopin, M. A. Janssen, E. Ostrom, and S. van der Leeuw. 2006. The globalization of socioecological systems: an agenda for scientific research. Global Environmental Change 16(3):304-316. http://dx.doi.org/10.1016/ j.gloenvcha.2006.03.004

Young, O. R., L. A. King, and H. Schroeder, editors. 2008. Institutions and environmental change: principal findings, applications, and research frontiers. MIT Press, Cambridge, Massachusetts, USA. http://dx.doi.org/10.7551/mitpress/9780262240574.001.0001

Zoomers, A., M. Leung, and G. van Westen. 2016. Local development in the context of global migration and the global land rush: the need for a conceptual update. Geography Compass 10(2):56-66. http://dx.doi.org/10.1111/gec3.12258 